\title{
Fibrosarcoma pada anjing golden retriever di Rumah Sakit Hewan Pendidikan Universitas Airlangga
}

\author{
Miyayu Soneta Sofyan ${ }^{1, *}$, Koesnoto Supranianondo ${ }^{2}$, Ira Sari Yudaniayanti ${ }^{3}$, Aisyah Novasari ${ }^{4}$, \\ Endah Paraswati ${ }^{5}$
}

${ }^{1}$ Departemen Kesehatan, Fakultas Vokasi, Universitas Airlangga, Surabaya

${ }^{2}$ Departemen Produksi Ternak, Fakultas Kedokteran Hewan, Universitas Airlangga, Surabaya

${ }^{3}$ Departemen Klinik Veteriner, Fakultas Kedokteran Hewan, Universitas Airlangga, Surabaya

${ }^{4}$ Rumah Sakit Hewan Pendidikan, Universitas Airlangga, Surabaya

${ }^{5}$ Program Pendidikan Profesi Dokter Hewan, Fakultas Kedokteran Hewan, Universitas Airlangga, Surabaya

\begin{abstract}
The dog named Agra (Golden Retriever) is suspected of having an axillary tumor. After surgery and examination of the pathology laboratory, it was found that the dog had fibrosarcoma in the axillaries. Fibrosarcoma is a malignant neoplasm that originates from mesenchymal cells, where the dominant cell histology is fibroblast cells that divide excessively and uncontrollably, can attack local tissues, and can move to other locations in the body (metastatic). The histopathological features of fibrosarcoma have fusiform or spindle-shaped cell fascicular growth patterns. The boundary between cells appears unclear with little cytoplasm and collagen fibers form parallel webbing. Grading histology is mainly based on the degree of cellularity, cell differentiation, mitotic features, and the amount of collagen produced by the cell necrosis. Surgery until now is the first and foremost thing in tumor therapy. Benign tumors can be removed with various surgical techniques depending on the location of the tumor. As for malignant tumors, surgery can be carried out by following other additional therapies to inhibit tumor growth

Keywords:

dog, neoplasm, fibrosarcoma, surgery, histopathology
\end{abstract}

\section{- PENDAHULUAN}

Kanker merupakan suatu penyakit yang disebabkan oleh pertumbuhan sel-sel tubuh secara tidak normal dan tidak terkontrol. Sel-sel tersebut terbentuk karena mutasi gen, induksi bahan asing pada dalam tubuh seperti zat bahan tambahan makanan, radioaktif, oksidan, ataupun karsinogen yang dihasilkan oleh tubuh sendiri secara alamiah. Sel-sel yang mengalami transformasi terus-menerus berproliferasi dan menekan pertumbuhan sel normal (Diananda 2009).

Fibrosarcoma adalah neoplasma ganas yang berasal dari sel mesenkim, dimana secara histopatologi sel yang dominan adalah sel fibroblas yang membelah secara berlebihan dan tidak terkendali, dapat menyerang jaringan setempat dan dapat menuju lokasi lain dalam tubuh (bermetastase). Pembelahan sel yang tidak terkontrol dapat menginvansi jaringan lokal serta dapat bermetastase jauh ke bagian tubuh lain (Krygjer \& Velerae 2009). Fibrosarcoma merupakan bentuk kejadian tumor yang sering terjadi pada anjing ras besar, berumur muda ( $<7$ tahun), menyerang daerah gingival dan palatum. Jenis tumor ini dapat bersifat malignant atau benign. Jenis benign dapat terjadi pada anjing berumur $<2$ tahun. Tulisan ini melaporkan teknik diagnosa dan penanganan kasus fibrosarcoma pada anjing golden retriever yang dilakukan di Rumah Sakit Hewan Pendidikan Universitas Airlangga Surabaya.

\section{- KASUS}

Anamnesa dan sinyalemen: Anjing Golden Retriver bernama Agra, jenis kelamin jantan dengan umur 9 tahun dibawa ke Rumah Sakit Hewan Pendidikan FKH UNAIR Surabaya. Hasil anamnesa pemilik, terdapat benjolan didekat kaki kanan depan, makan dan minum normal, urinasi dan defekasi normal, benjolan sudah hampir 1 tahun. Pemeriksaan fisik: Suhu rektal $38,5{ }^{\circ} \mathrm{C}$, frek. pulsus $96 \mathrm{kali} /$ menit, frek. nafas $24 \mathrm{kali} /$ menit, berat badan $25 \mathrm{~kg}$, turgor 1 detik, dan CRT 1 detik. Kondisi umum normal, namun kelenjar limfa axillaris terdapat benjolan keras. Terapi: Bedah mengangkat benjolan pada bagian axillaris. Pemeriksaan penunjang: Pemeriksaan histopatologi jaringan dilakukan di Lab. Patologi FKH Unair. Diagnosa: Fibrosarcoma pada bagian axilaris.

\section{- HASIL DAN PEMBAHASAN}

Bedah dilakukan untuk mengangkat jaringan tumor pada axilaris anjing. Jaringan tumor kemudian dibuat preparat histopatologi untuk identifikasi jenis tumor (Sriwibowo

Diterima: 05-03-2020 | Direvisi: 10-04-2020 | Disetujui: 15-04-2020

(C) 2020 CC-BY-SA. Ini adalah artikel Open Access yang didistribusikan berdasarkan ketentuan dari Creative Commons Attribution ShareAlike 4.0 International License (https://creativecommons.org/licenses/by-sa/4.0/). 
2005). Hasil dari pembacaan dan identifikasi tumor, disimpulkan bahwa anjing terkena fibrosarcoma. Terapi ideal yang seharusnya diberikan pada hewan yang didiagnosa fibrosarcoma adalah bedah dengan diikuti radiasi dan kemoterapi. Terapi berupa bedah pengangkatan tumor, tanpa disertai radiasi maupun kemoterapi pada penanganan sehingga perlu dilakukan pemantauan teratur terhadap kesehatan tubuh anjing, seperti pola makan dan tidak makan sembarangan, menjaga kebersihan tubuh dan lingkungan serta menjauhkan dari hal-hal yang dapat memicu timbulnya tumor atau kanker.

Fibrosarcoma dapat dikenali sebagai massa berinfiltrasi besar, lunak, putih, dan kelabu mutiara. Area nekrosis atau perdarahan sering terdapat yang mencerminkan bahwa kecepatan tumbuh jaringan diluar kemampuan perbekalan darah. Secara histopatologi, lesi menunjukkan berbagai derajat anaplasi. Beberapa fibrosarcoma berdiferensiasi dengan baik dengan ditandai oleh fibroblas yang tampak matur dengan beberapa sel mitosis dan beberapa plemorfiringan (Robbins \& Kumar 1995).

Secara makroskopis fibrosarcoma mempunyai ciri-ciri fenotip dengan pertumbuhan yang berlebih, invasi lokal dan mempunyai kemampuan penyebaran yang jauh. Sifat-sifat tersebut ditemukan pada tahap-tahap penampilan suatu fenomena yang disebut progresif kanker. Secara mikroskopis fibrosarcoma mempunyai ciri-ciri: susunan sel yang tidak teratur, selularitas yang padat, terdapat banyak sel dan ukuran sel yang berbeda (pleomorphism), inti sel membesar, kromatin menebal, kasar, tidak rata, terjadi hiperkromasi dan basofilik (Gambar 1). Anak inti tajam dan sering menonjol dengan ukuran yang bervariasi serta terjadi banyak mitosis. Bentuk inti bermacam-macam dan kromosomnya aneuploid. (Cotran et al. 1999).

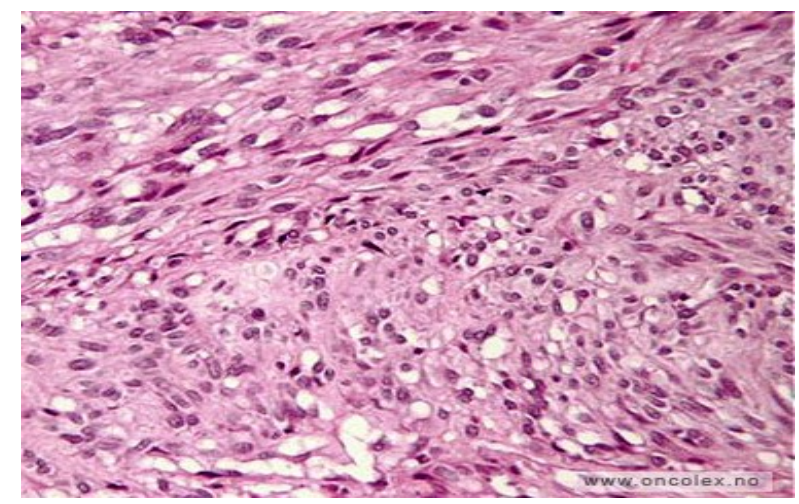

Gambar 1 Histopatologi fibrosarcoma pada subkutan (Onkolex,

2014). a; pleomorfism, b. susunan se tidak teratur, c: bentuk basofilik.

Fibrosarcoma dapat terjadi akibat pengaruh paparan radiasi dari lingkungan yang mengakibatkan terjadinya translokasi kromosom pada sekitar 90\% kasus. x-radiation dan gamma radiation paling berpotensi menyebabkan kerusakan jaringan. Ionisasi radiasi menyebabkan terjadinya perubahan genetik yang meliputi mutasi gen, mutasi minisatellit (perubahan jumlah DNA sequences), formasi mikronukleus (tanda kehilangan atau kerusakan kromosom), aberasi kromosomal (struktur dan jumlahnya), perubahan ploidi (jumlah dan susunan kromosom), DNA stand breaks dan instabilitas kromosom. Ionisasi radiasi mempengaruhi semua fase dalam siklus sel, namun fase $\mathrm{G}_{2}$ merupakan yang paling sensitif (Ortho Bullets 2014).

Sepanjang hidup sel baik pada sumsum tulang, mukosa usus, epitelium testikular seminuferus, maupun folikel ovarium yang selalu mengalami proses mitosis sangat rentan terhadap trauma. Iradiasi selama proses mitosis mengakibatkan aberasi kromosomal. Tingkat kerusakan bergantung pada intensitas, durasi, dan kumulatif dari radiasi. DNA dapat mengalami kerusakan secara langsung maupun tidak langsung melalui interaksi dengan reactive products yang berupa radikal bebas. Pengamatan terhadap kerusakan DNA diduga sebagai hasil perbaikan DNA atau sebagai akibat dari replikasi yang salah. Perubahan ekspresi gen memicu timbulnya suatu tumor. Paparan $x$-radiation dan gamma radiation sangat kuat berkorelasi terhadap timbulnya keganasan atau kanker pada jaringan. Kerusakan DNA yang dimanifestasikan dalam bentuk translokasi kromosom gene COL1A1 pada kromosom 17 dan gen platelet-derived growth factor $B$ pada kromosom 22 mengakibatkan terjadinya keganasan pada jaringan fibrous. Perubahan fibrosarcoma dicirikan dengan pertumbuhan pola herring bone yang nampak pada klasik fibrosarcoma (Wong 2008).

\section{- SIMPULAN}

Berdasarkan anamnesis, pemeriksaan fisik, gejala dan tanda klinis, dilakukan pembedahan dan identifikasi patologi jaringan diketahui bahwa anjing golden retriever bernama Agra di diagnosa fibrosarcoma pada bagian axilaris.

\section{- INFORMASI PENULIS}

Penulis untuk Korespondensi

*MSS: miyayu@vokasi.unair.ac.id

Departemen Kesehatan, Fakultas Vokasi, Universitas Airlangga, Surabaya

\section{- PUSTAKA ACUAN}

Cotran RS, Kumar V, Collins T. 1999. Pathologic Basis of Disease, 6th ed. Philadelphia: Saunders

Diananda R. 2009. Panduan Lengkap Mengenal Kanker:Serviks, Payudara, Prostat, Usus Besar Lambung, Paru-Paru. Jogyakarta: Mirza Media Pustaka.

Krygjer JE, Valerae L. 2009. Fibrosarcoma of Bone: Review of A Rare Primary Malignancy of Bone. San Jose. http://terryhealey.com/wpcontent/Fibrosarkoma.pdf. [Diakses tanggal 30 Agustus 2018].

Ortho Bullets. 2014. Pathology Fibrosarcoma of Bone. http://www.orthobullets.com [Diakses tanggal 30 Agustus 2018].

Robbins SL, Kumar V. 1995. Buku Ajar Patologi I, Edisi 4. Jakarta: EGC.

Sriwibowo K. 2005. Akurasi Biopsi Aspirasi Jarum Halus sebagai Sarana dalam Menegakkan diagnosa Neoplasma Ganas Jaringan Lunak. Bagian Ilmu Bedah Fakultas Kedokteran Universitas Diponegoro. Semarang. pp : 5-10

Wong SL. 2008. Diagnosis and management of desmoid tumors and fibrosarcoma. Journal of Surgical Oncology. 97(6): 554-558. 
